\title{
Isolation of precise plastid deletion mutants by homology- based excision: A resource for site-directed mutagenesis, multi-gene changes and high-throughput plastid transformation
}

DOI:

10.1111/j.1365-313X.2006.02736.x

Link to publication record in Manchester Research Explorer

\section{Citation for published version (APA):}

Kode, V., Mudd, E. A., lamtham, S., \& Day, A. (2006). Isolation of precise plastid deletion mutants by homologybased excision: A resource for site-directed mutagenesis, multi-gene changes and high-throughput plastid transformation. Plant Journal, 46(5), 901-909. https://doi.org/10.1111/j.1365-313X.2006.02736.x

\section{Published in:}

Plant Journal

\section{Citing this paper}

Please note that where the full-text provided on Manchester Research Explorer is the Author Accepted Manuscript or Proof version this may differ from the final Published version. If citing, it is advised that you check and use the publisher's definitive version.

\section{General rights}

Copyright and moral rights for the publications made accessible in the Research Explorer are retained by the authors and/or other copyright owners and it is a condition of accessing publications that users recognise and abide by the legal requirements associated with these rights.

\section{Takedown policy}

If you believe that this document breaches copyright please refer to the University of Manchester's Takedown Procedures [http://man.ac.uk/04Y6Bo] or contact uml.scholarlycommunications@manchester.ac.uk providing relevant details, so we can investigate your claim.

\section{OPEN ACCESS}




\title{
Isolation of precise plastid deletion mutants by homology-based excision: a resource for site-directed mutagenesis, multi-gene changes and high-throughput plastid transformation
}

\author{
Vasumathi Kode, Elisabeth A. Mudd, Siriluck lamtham ${ }^{\dagger}$ and Anil Day ${ }^{*}$ \\ Faculty of Life Sciences, The University of Manchester, 3.614 Stopford Building, Oxford Road, Manchester M13 9PT, UK
}

Received 24 October 2005; revised 31 January 2006; accepted 8 February 2006.

*For correspondence (fax +44 161275 3938; e-mail anil.day@manchester.ac.uk).

${ }^{\dagger}$ Present address: Kasetsart University, Kampangsaen Campus, Nakorn Prathom 73140, Thailand.

\begin{abstract}
Summary
We describe a simple and efficient homology-based excision method to delete plastid genes. The procedure allows one or more adjacent plastid genes to be deleted without the retention of a marker gene. We used aadAbased transformation to duplicate a 649 bp region of plastid DNA corresponding to the atpB promoter region. Efficient recombination between atpB repeats deletes the intervening foreign genes and $1984 \mathrm{bp}$ of plastid DNA (co-ordinates 57 424-59 317) containing the $r b c \mathrm{~L}$ gene. Only five foreign bases are present in $\triangle r b c L$ plants illustrating the precision of homology-based excision. Sequence analysis of non-functional $r b c L$-related sequences in $\Delta r b c \mathrm{~L}$ plants indicated an extra-plastidic origin. Mutant $\Delta r b c \mathrm{~L}$ plants were heterotrophic, palegreen and contained round plastids with reduced amounts of thylakoids. Restoration of autotrophy and leaf pigmentation following aadA-based transformation with the wild-type $r b c \mathrm{~L}$ gene ruled out mutations in other genes. Excision and re-use of aad $A$ shows that, despite the multiplicity of plastid genomes, homology-based excision ensures complete removal of functional aadA genes. Rescue of the $\triangle r b c \mathrm{~L}$ mutation and autotrophic growth stabilizes transgenic plastids in heteroplasmic transformants following antibiotic withdrawal, enhancing the overall efficiency of plastid transformation. Unlike the available set of homoplasmic knockout mutants in 25 plastid genes, the $r b c L$ deletion mutant isolated here is readily transformed with the efficient aadA marker gene. This improvement in deletion design facilitates advanced studies that require the isolation of double mutants in distant plastid genes and the replacement of the deleted locus with site-directed mutant alleles and is not easily achieved using other methods.
\end{abstract}

Keywords: Nupts, photosynthesis, ribulose bisphosphate carboxylase/oxygenase, targeted gene deletion, tobacco.

Introduction

The simplicity and precision of homology-based excision, together with the predominance of homologous recombination in plastids, makes it a particularly attractive tool for manipulating plastid genomes. Use of native plastid enzymes avoids the extra transformation steps needed to introduce foreign site-specific recombinases, unintended site-specific recombinase-promoted rearrangements and the retention of site-specific recombinase target sites in engineered plastid genomes (Corneille et al., 2001, 2003; Hajdukiewicz et al., 2001; Lutz et al., 2004, 2006). Homologybased excision has allowed the removal of marker genes from transgenic plastids (Fischer et al., 1996; lamtham and Day, 2000; Klaus et al., 2004). However, the potential of exploiting native plastid recombination pathways to 
manipulate plastid DNA has not been fully explored. To improve the design of deletion mutants to facilitate advanced studies on plastid genes, we examine whether homology-based excision can be used to make precise deletions in plastid DNA without a requirement for a marker gene to select mutant plastids.

Loss-of-function plastid mutants resulting from precise targeted deletion of plastid genes without the insertion of marker genes have not been described in flowering plants. All described knockout mutations in 29 plastid genes contain targeted insertions of the aadA marker gene used to select transformed plastids (reviewed by Maliga, 2005). Marker-free plastid mutants would provide new opportunities and advantages compared to the use of conventional aadA insertion mutants and wild-type (WT) plants in transplastomic research. They can be transformed with aadA, which is the most widely used plastid transformation marker gene (Svab and Maliga, 1993) due to the relative inefficiency of alternative markers (Carrer et al., 1993; Huang et al., 2002; Svab et al., 1990). When a modified plastid gene containing a site-directed mutation is transformed into a deletion mutant, all transformants will contain the modified allele whose phenotype will not be masked by the resident wild-type allele. The introduction of site-directed mutations into WT plastids can be problematic due to undesirable recombination events in the region between marker and mutation (Andrews and Whitney, 2003; Whitney et al., 1999). Marker-free mutants facilitate the stepwise introduction of mutations into the plastid genome to isolate plants with mutations in several plastid genes. Co-transformation with two plasmids provides a less predictable method for integrating changes at multiple sites within the plastid genome (Carrer and Maliga, 1995; Ye et al., 2003). Efficient aadA-based antibiotic selection combined with mutant rescue using the wild-type plastid allele (Klaus et al., 2003) enables rapid identification of plastid transformants and stabilizes recombinant genomes in transformed plants. This provides the basis for high-throughput aadA-based transformation of foreign trait genes into plastids. Pleiotropic effects of marker gene expression on transcription or protein accumulation within mutant plastids are removed, and marker-free plastid mutants are likely to satisfy regulatory approval for widespread dissemination and use of plastid mutants within the research community.

Here we target the $r b c L$ gene, which encodes the large subunit (LS) of ribulose bisphosphate carboxylase/oxygenase (RuBisCO), the key enzyme in photosynthetic carbon assimilation (Andrews and Whitney, 2003; Parry et al., 2003). Our procedure is simple, can be used to delete one or more adjacent plastid genes, and is applicable to non-essential plastid genes, whose mutation allows growth on media containing sucrose.

\section{Results}

\section{Plastid transformation vectors and experimental design}

The approach we used to delete the $r b c \mathrm{~L}$ gene is illustrated in Figure 1(a). In vector pUM83, the aadA marker gene is placed downstream of the $r b c L$ gene. Sequences upstream of $r b c \mathrm{~L}$ are duplicated and placed downstream of $r b c \mathrm{~L}$ and aadA. This creates a direct repeat flanking $r b c \mathrm{~L}$ and aadA. Recombination between these direct repeats excises the $r b c L$ and aadA genes in one event. The advantage of this strategy is that all mutant $\Delta r b c L$ cells will also be free of the aadA marker gene. This means that a visual screen for plastid mutants, which often have a pigment-deficient phenotype (Kanevski and Maliga, 1994; Klaus et al., 2003; Swiatek et al., 2003), will also identify aadA-free plants.

Vector pUM83 (Figure 1a) contains converging expression cassettes with the aadA marker (Goldschmidt-Clermont, 1991) and uidA reporter genes (Jefferson, 1987) inserted into the Aocl site located in the intergenic region between the $r b c \mathrm{~L}$ and $a c c \mathrm{D}$ genes (Wakasugi et al., 2001). The $5^{\prime}$ atpB regulatory region drives expression of $u i d \mathrm{~A}$ and is comprised of 649 bases including the ATG initiation codon. This creates two 649 bp direct repeats, DR1 and DR2 (Figure 1a), comprised of $5^{\prime}$ atpB regulatory sequences that flank the $r b c L$ gene. The $5.7 \mathrm{kbp}$ left and $2.1 \mathrm{kbp}$ right plastid (pt) DNA sequences bordering aadA and uidA target integration by homologous recombination following plastid transformation. Transgenic plastid genomes are then selected with antibiotics to replace WT plastids. A recombination event between the 649 bp direct repeats will excise the $r b c L$, aadA and uidA genes as a $6.1 \mathrm{kbp}$ circle with a single HindIII site, leaving a $153 \mathrm{kbp}$ marker-free $\Delta r b c \mathrm{~L}$ plastid genome (Figure 1a). The $6.1 \mathrm{kbp}$ circle lacks sequences necessary for stable maintenance as an episome and is lost. In the absence of selection, marker-free $\Delta r b c \mathrm{~L}$ plastid genomes will accumulate, leading to the isolation of marker-free mutant plants.

\section{Isolation of pUM83 ( $\left.T_{0}\right)$ plastid transformants selected with antibiotics}

Plastid transformation was carried out using particle bombardment on leaf explants (Kode et al., 2005). Green resistant shoots were taken through three rounds of regeneration on media containing spectinomycin and streptomycin. Of seven antibiotic-resistant clones isolated, three stained positive for GUS using X-gluc (not shown), indicating the presence of an active uidA gene. Two of these GUS-positive clones (8a and 8c) were taken forward for further analysis. DNA blot analysis indicated replacement of WT ptDNA with transgenic plastid genomes (see below). Seeds were collected from selfed $T_{0}$ pUM83 transplastomic plants. 
(a)

Vector
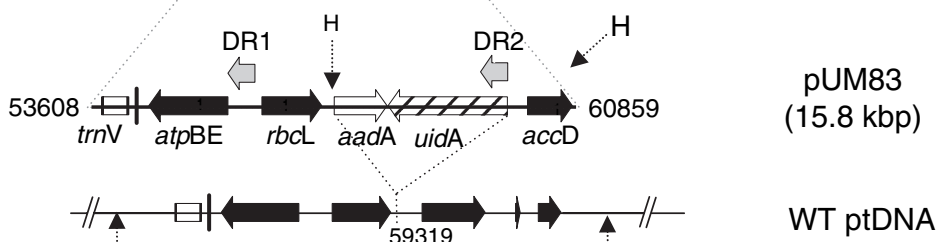

trnV $\sum_{S} a t p B E \quad r b c L a c c D$ psal ycf4 $\quad$ (155.9 kbp)

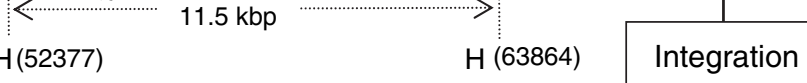

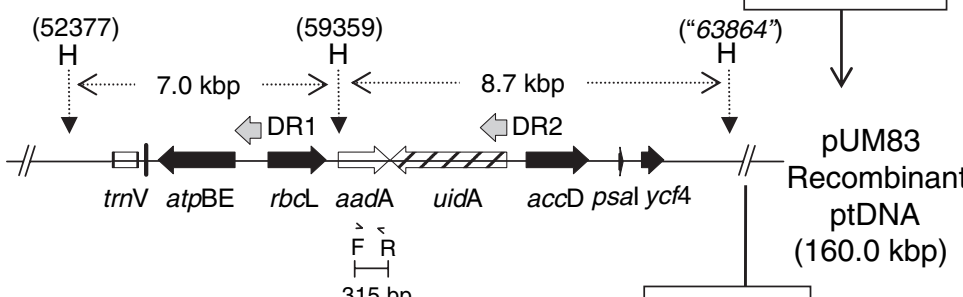

(59367) (PCR)

Probes:rbcL aadA

Excision DR $1+2$

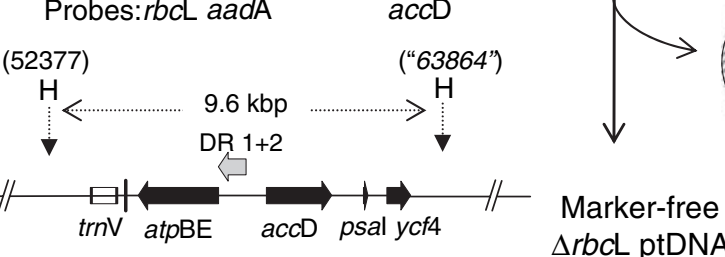

Deleted 1894 bp (co-ordinates 57424-59317) (153.4 kbp)

(b)

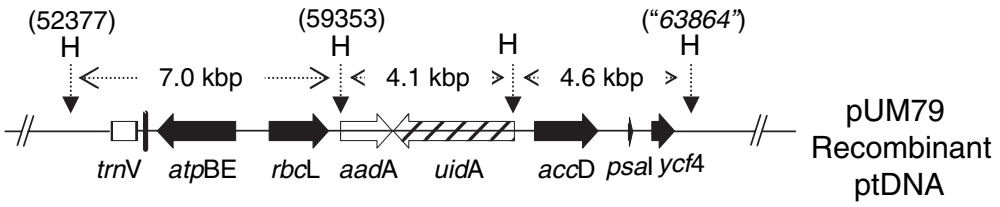

Figure 1. Plastid DNA recombination events underlying deletion and restoration of $r b c L$.

(a) Scheme showing isolation of $\Delta r b c L$ plastid (pt) DNA. Left (map co-ordinates 53 608-59 318) and right (59 319-60 859) ptDNA sequences in vector pUM83 target integration of aadA and uidA into WT ptDNA by homologous recombination. Recombination between 649 bp direct repeats DR1 and DR2 comprised of the atpB ATG initiation codon and upstream region excises a $6.1 \mathrm{kbp}$ circle with foreign and $r b c \mathrm{~L}$ genes to leave a marker-free $\Delta r b c L$ plastid genome. DR1, DR2 and the DR1+2 products of recombination are identical.

(b) Integration pattern of the pUM79 vector. Shown are HindIII ( $\mathrm{H})$ sites and fragments that hybridize to $r b c \mathrm{~L}$, aadA and accD probes. $\mathrm{Plastid} r b c \mathrm{~L}$, accD, psal and $y c f 4$ genes and foreign genes are indicated. Hybridization probes and aadA F + R primers are located. The WT ptDNA HindllI site at 63894 bp is indicated as ' 63864 ' in recombinant and $\Delta r b c L$ ptDNAs.

\section{Isolation of $\Delta \mathrm{rbcL}$ mutant plants ( $T_{1}$ generation)}

Seeds from pUM83-8a and -8c transplastomic parents were germinated on MS medium containing spectinomycin $\left(500 \mathrm{mg} \mathrm{l}^{-1}\right)$ or MS medium without antibiotics. All of the $30 \mathrm{pUM} 83-8 \mathrm{a}\left(\mathrm{T}_{1}\right)$ seedlings were green and resistant to spectinomycin (not shown). Two white sensitive seedlings were found amongst the $30 \mathrm{~T}_{1}$ progeny of pUM83-8c grown on spectinomycin-containing medium (Figure 2a) and resembled spectinomycin-bleached WT seedlings. On antibiotic-free medium, three pale-green pUM83-8c seedlings
(Figure 2b) were found amongst $30 \mathrm{~T}_{1}$ seedlings and were propagated in vitro for further analysis. On further growth on MS medium without antibiotics, half of the $T_{1}$ seedlings from pUM83-8a and -8c plastid transformants gave rise to plants with one or more true leaves containing pale-green sectors (Figure 2c). WT plants do not contain pale-green sectors (Figure $2 \mathrm{~d}$ ). $T_{2}$ seeds were collected from variegated $T_{1}$ plants, allowing long-term storage of the mutant (Figure 2e,f).

A pale-green phenotype is characteristic of mutations in some photosynthesis-related genes (Klaus et al., 2003; 

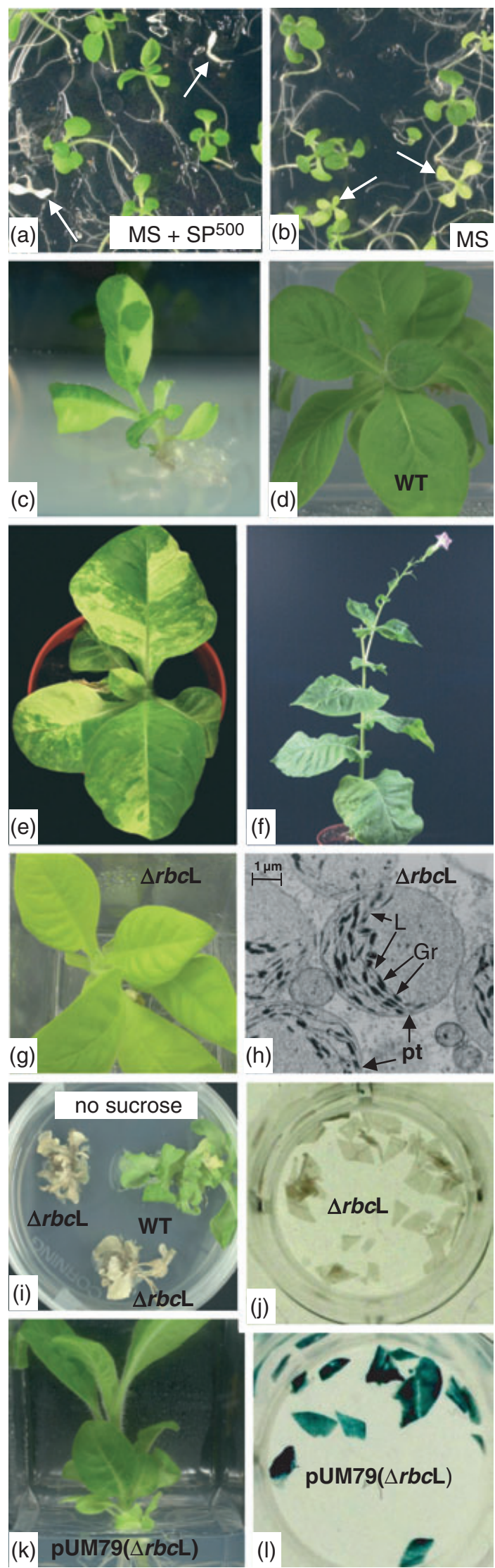

Swiatek et al., 2003) including rbcL (Kanevski and Maliga, 1994). Sensitivity to spectinomycin and a pale-green phenotype would result from excision of the aadA and $r b c L$ genes (Figure 1). To purify pale-green mutant plants, three rounds of regeneration were performed on media lacking antibiotics using either leaves from pale-green plants (clone 8c) or palegreen sectors from variegated plants (clone 8a). Pale-green mutant plants (Figure $2 \mathrm{~g}$ ) were propagated by sub-culturing shoots on MS medium supplemented with $3 \% \mathrm{w} / \mathrm{v}$ sucrose.

\section{$P C R$ analysis of $\triangle \mathrm{rbcL}$ mutant plants and sequencing confirms the precision of homologous recombination}

Recombination within the duplicated atpB promoter region excises $r b c L$ and the foreign genes. The precision of the recombination event was analysed by PCR using primers $p t$ $F$ and pt $R$ (Figure $3 c$ ). The primers amplified a $3.2 \mathrm{kbp}$ band from WT DNA (Figure 3a) and a $1.3 \mathrm{kbp}$ band from palegreen $\Delta r b c L-8 a$ plant DNA (Figure 3a). The absence of a WT $3.2 \mathrm{kbp}$ band in $\Delta r b c \mathrm{~L}$ lanes is consistent with the absence of WT ptDNA but might also reflect preferential amplification of the smaller $1.3 \mathrm{kbp}$ band. The $1.3 \mathrm{kbp}$ amplification product from $\Delta r b c \mathrm{~L}$ plants was purified and sequenced. The sequence (Figure 3c) confirmed that the $1.3 \mathrm{kbp}$ PCR product was the result of recombination between the $649 \mathrm{bp}$ direct repeats (Figure 1a). No changes were found in the recombined copy of the $649 \mathrm{bp}$ atpB $5^{\prime}$ region remaining in $\Delta r b c \mathrm{~L}$ plants, demonstrating a perfect homologous recombination event between the two repeats. An introduced Notl site spans the junction between the deletion end points located at bases 57423 and 59318 . The $\Delta r b c L$ plastid genome contains only $5 \mathrm{bp}$ of foreign sequence (GGCCG) corresponding to internal bases in the Notl site (Figure 3c). The $\Delta r b c L$ plants should lack the aadA marker gene. Primers directed against aadA (see locations in Figure 1) amplified a band of the expected size from a uniformly dark-green pUM83-8a $\left(T_{0}\right)$ plant DNA but not from WT or pale-green $\Delta r b c$-8a extracts (Figure $3 \mathrm{~b}$ ).

\section{DNA blot analyses of $\Delta \mathrm{rbcL}$ mutant plants}

Total DNA was extracted from WT plants, a uniformly darkgreen pUM83-8a $\left(\mathrm{T}_{0}\right)$ plant and two $\Delta r b c \mathrm{~L}$ mutant clones $(8 \mathrm{a}$,

Figure 2. Isolation and phenotype of $\Delta r b c \mathrm{~L}$ plants.

(a) pUM83 transplastomic $8 \mathrm{c}\left(\mathrm{T}_{1}\right)$ seedlings on MS medium with spectinomycin (500 $\mathrm{mg} \mathrm{I}^{-1}$ ), white seedlings arrowed; (b) pUM83 transplastomic 8c $\left(\mathrm{T}_{1}\right)$ seedlings on MS medium, pale-green seedlings arrowed; (c) pUM83 transplastomic 8a $\left(T_{1}\right)$ plant with sectors on MS medium; (d) WT plant growing on MS medium; (e, f) pUM83 $8 \mathrm{a}\left(\mathrm{T}_{1}\right)$ transplastomic plants growing in soil; (g) $\Delta r b c \mathrm{~L}$ plants growing on MS medium; (h) plastids (pt) in $\Delta r b c \mathrm{~L}$ leaves, magnification $11000 \times$, plastids (pt), stroma lamellae (L), grana (Gr); (i) WT and $\Delta r b c L$ shoots placed on RMOP media lacking sucrose for 3 weeks; (j) $\Delta r b c \mathrm{~L}$ leaves in X-gluc buffer showing GUS-negative phenotype; (k) antibiotic-resistant plant from $\Delta r b c L$ leaves transformed with pUM79; (I) leaves from pUM79 transformant in X-gluc buffer showing GUS-positive phenotype. 
(a)

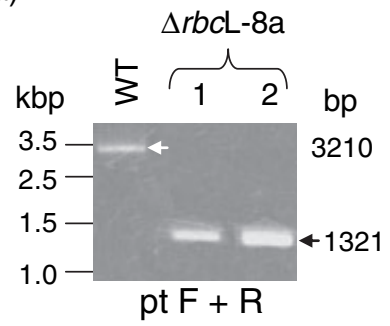

(b)

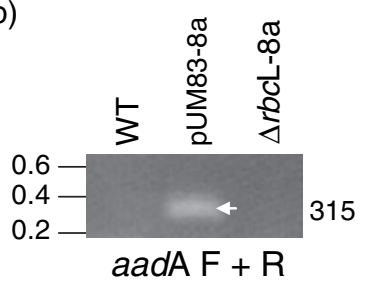

(c)

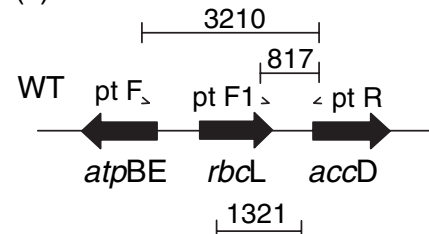

$\Delta r b c L$
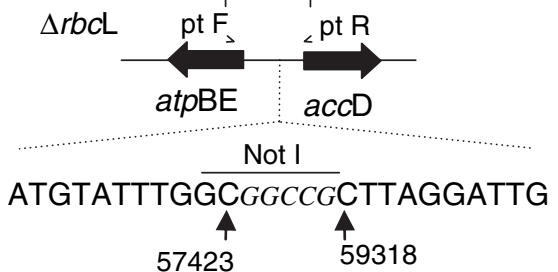

Deleted 1894 bases

Co-ordinates 57424-59317

Figure 3. PCR analysis on pUM83 transplastomic and $\Delta r b c L$ DNA.

Sources of plant DNA are indicated above lanes. Marker sizes are shown on the left of each gel photograph. (a) pt $\mathrm{F}$ and $\mathrm{R}$ primers flank the $r b c \mathrm{~L}$ deletion and amplify a smaller product from $\Delta r b c \mathrm{~L}$ plant extracts; $1 \% \mathrm{w} / \mathrm{v}$ agarose gel; (b) aadA-F and $\mathrm{R}$ primers (located in Figure 1a) fail to amplify a product using WT and $\Delta r b c L-8 A$ extracts, $2 \% \mathrm{w} / \mathrm{v}$ agarose gel; (c) location of primers on WT and $\Delta r b c \mathrm{~L}$ ptDNA. The binding site for pt F1 is not present in $\Delta r b c \mathrm{~L}$ ptDNA. Sizes of expected PCR products and the sequence at the junction of the $r b c \mathrm{~L}$ deletion are shown.

8c) from independent pUM83 transformants $8 \mathrm{a}$ and 8c. The locations of $r b c \mathrm{~L}, a c c \mathrm{D}$ and $\operatorname{aadA}$ hybridization probes are shown in Figure 1(a). An $r b c L$ probe hybridizes to an $11.5 \mathrm{kbp}$ Hindlll band in digests of WT DNA (Figure 4a, lane 1). This is replaced by two bands of 7.0 and $6.1 \mathrm{kbp}$ in digests of leaf DNA from a $T_{0}$ pUM83-8a plant (Figure 4a, lane 2). The $7.0 \mathrm{kbp}$ band corresponds to the recombinant plastid genome resulting from integration of aadA and uidA expression cassettes (Figure 1a). The less intense $6.1 \mathrm{kbp}$ Hindlll band corresponds in size to the predicted excision product containing foreign genes and $r b c L$ that has a single
Hindlll site (Figure 1a) and also hybridizes to aadA (Figure $4 d$, lane 2). A discrete low molecular weight band of uncut DNA from a $T_{0}$ pUM83-8a plant (Figure 4b, lane 2), located well below the shear size of the bulk of DNA (>20 kbp), might correspond to the $6.1 \mathrm{kbp}$ excision product. No low molecular weight species were found in other lanes (Figure 4b).

No $r b c \mathrm{~L}$ hybridization was expected to digests of $\Delta r b c \mathrm{~L}$ plant DNA, but we found a weakly hybridizing 11.5 HindIII band (Figure 4a, lanes 3 and 4) that co-migrates with the strong WT band (Figure 4, lane 1). This faint $11.5 \mathrm{kbp}$ band is unlikely to represent residual copies of WT plastid genomes because WT ptDNA in mutant plants would be expected to give rise to green sectors. No dark-green sectors have been observed in $\Delta r b c L$ mutant plants propagated for three years on MS media. This indicates that the $r b c \mathrm{~L}$ related sequences in $\Delta r b c \mathrm{~L}$ plants are not functional. Primers pt F1 and pt R (a)

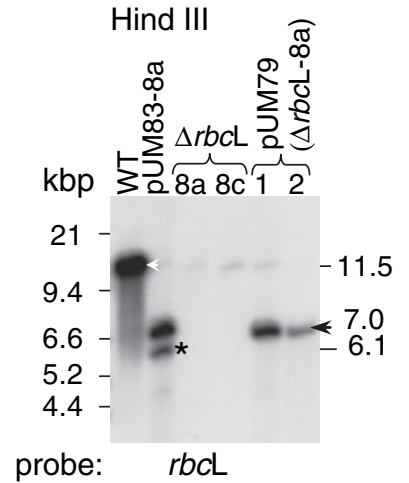

(c)

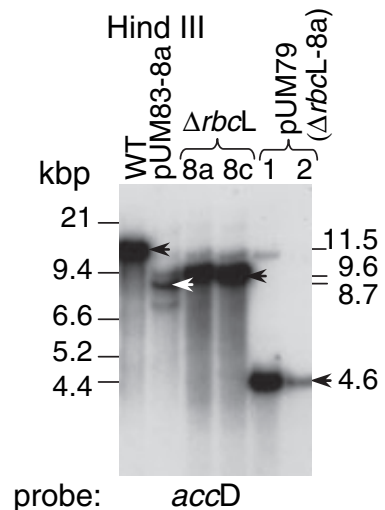

(b)

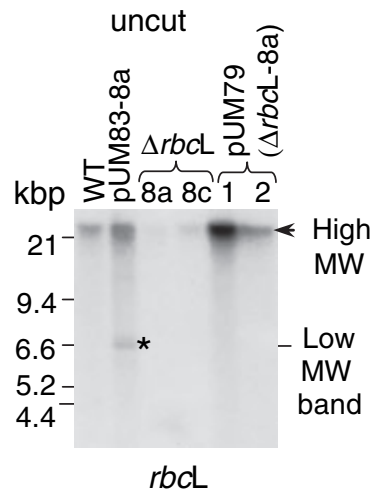

(d)

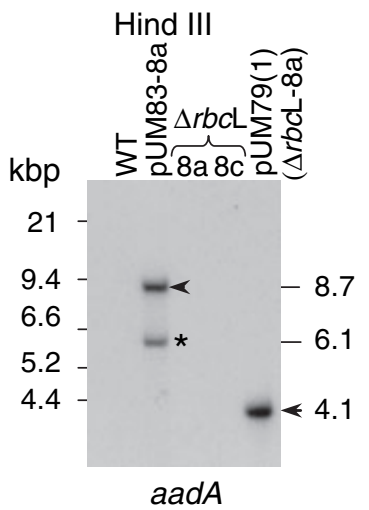

Figure 4. DNA blot analyses on pUM83 transplastomic $\left(\mathrm{T}_{0}\right), \Delta r b c \mathrm{~L}$ mutant $\left(\mathrm{T}_{1}\right)$ and pUM79 transformants of $\Delta r b c L$ plants.

Sources of total DNA preparations are indicated above lanes. DNA was either digested with HindIII $(a, c, d)$ or untreated (b) before loading on $0.8 \% \mathrm{w} / \mathrm{v}$ agarose gels. Blot wash conditions: $0.1 \times \mathrm{SSC}$ at $60^{\circ} \mathrm{C}$. Bands marked with an asterisk are derived from the $6.1 \mathrm{kbp}$ episome. Hybridization probes (located in Figure 1a) are indicated below each panel. Linear dsDNA size standards (left) and hybridizing band sizes (right) are shown beside the panels. 


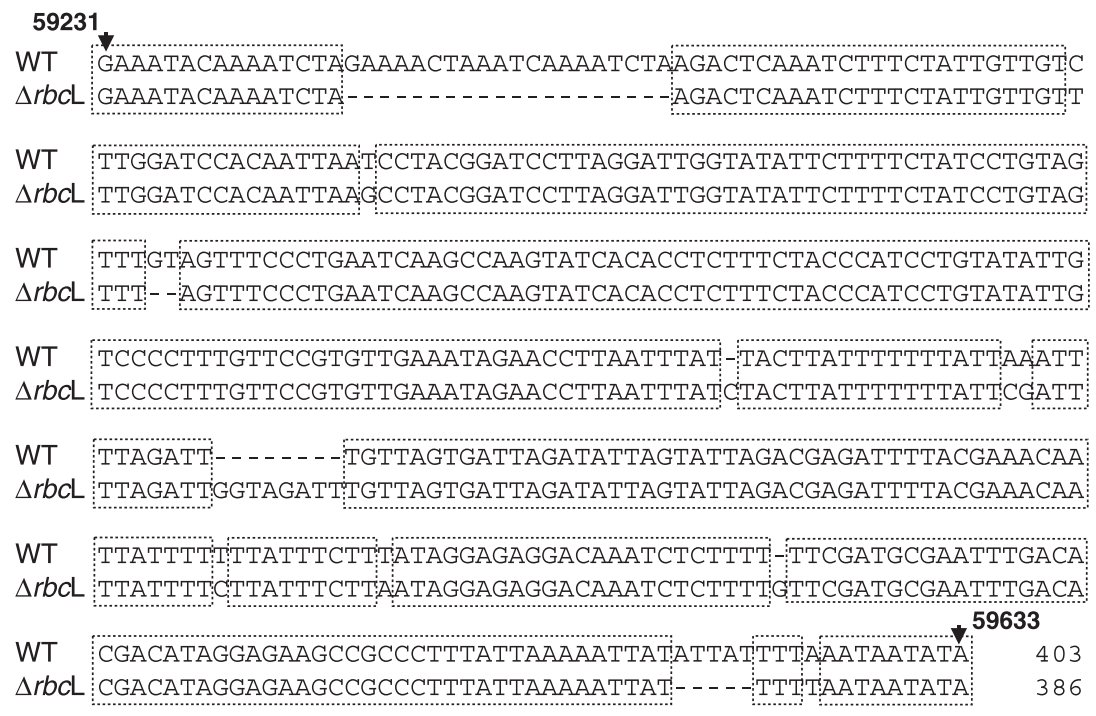

Figure 5. Alignment of WT ptDNA sequence (co-ordinates 59 231-59 633) with $\Delta r b c L$ PCR product using primers pt $\mathrm{F} 1$ and pt R (see Figure 3c). (locations shown in Figure 3c) should amplify residual copies of any WT DNA present in $\Delta r b c L$ plants because primer pt $\mathrm{F} 1$ binds to the end of the $r b c \mathrm{~L}$ gene, which is deleted in $\Delta r b c \mathrm{~L}$ plants. A $0.8 \mathrm{kbp}$ PCR product amplified from $\Delta r b c L$ DNA contained seven base substitutions and six insertion/deletion events in a 386 bp region when compared to WT ptDNA (Figure 5). This sequence divergence is typical of plastid DNA sequences transposed to the nucleus (Huang et al., 2005). No WT rbcL sequences were detected in $\Delta r b c \mathrm{~L}$ plants.

Hybridization of the $a c c D$ probe to Hindlll digests revealed an $11.5 \mathrm{kbp}$ WT band (Figure 4c, lane 1), an $8.7 \mathrm{kbp}$ band in pUM83 transformants (Figure 4c, lane 2), and a $9.6 \mathrm{kbp}$ band in $\Delta r b c L$ plants (Figure $4 c$, lanes 3 and 4) as expected (see Figure 1a). An aadA probe hybridizes to expected bands of 8.7 and $6.1 \mathrm{kbp}$ in pUM83 transformants (Figure 4d, lane 2) but did not hybridize to digests of WT and $\Delta r b c L$ DNA (Figure 4d, lanes 1, 3, 4); refer to maps in Figure 1(a) for sizes. Blot analyses confirm the isolation of aadA-free $\Delta r b c \mathrm{~L}$ mutant plants.

\section{Phenotype of $\Delta \mathrm{rbcL}$ plants}

Sections of pale-green $\Delta r b c L$ leaves contained a predominance of circular plastids (pt) in which stroma lamellae (L) and grana $(\mathrm{Gr}$ ) were clearly visible (Figure $2 \mathrm{~h}$ ). Much of the stroma was devoid of grana and stroma lamellae, unlike the typical lens-shaped chloroplasts found in leaf mesophyll cells in WT plants (see examples of WT plastids in Kode et al., 2005; Swiatek et al., 2003). Shoots formed on RMOP regeneration medium supplemented with $3 \% \mathrm{w} / \mathrm{v}$ sucrose were transferred to RMOP medium lacking sucrose. WT shoots continued to grow on RMOP medium lacking sucrose while $\Delta r b c \mathrm{~L}$ shoots from clone $8 \mathrm{a}$ died (Figure 2i). This indicates that mutant $\Delta r b c \mathrm{~L}$ plants are heterotrophic and unable to grow on media lacking sucrose. The large subunit (LS) of RubisCO was not detected in $\Delta r b c \mathrm{~L}$ mutant plants by Western blot analysis (not shown).

Repair of the lesion in $\Delta \mathrm{rbc} L$ mutant plants by transformation with the WTgene

Transformation of $\Delta r b c \mathrm{~L}$ plants with plastid transformation vector pUM79 introduces aadA and the WT rbcL allele into mutant plastids (Figure 1b). The HindIII restriction patterns of recombinant ptDNA in pUM79 and pUM83 transformants are different (see Figure 1a,b). This allows us to distinguish pUM79 transformants from the primary pUM83 transformants from which the $\Delta r b c \mathrm{~L}$ plants, used as recipients of transformation, were derived. Spectinomycinresistant shoots with either dark-green or pale-green leaves were isolated 4-8 weeks after transformation. PCR analyses with aadA primers indicated the presence of aadA in dark-green leaves and its absence in pale-green leaves (not shown). The pale-green resistant plants resembled the colour of the $\Delta r b c \mathrm{~L}$ recipient used for transformation and were likely to be spontaneous spectinomycin-resistant mutants, a common problem with spectinomycin-based selection (Klaus et al., 2003). Shoots were transferred to Magenta jars for rooting without further cycles of regeneration. Dark-green clones (Figure $2 \mathrm{k}$ ) stained blue with X-Gluc (Figure 2I), indicative of the presence of the uidA gene, whereas the pale-green resistant shoots and recipient $\Delta r b c \mathrm{~L}-8 \mathrm{a}$ plant (Figure $2 \mathrm{~g}$ ) used for transformation were GUS-negative (Figure 2j). Leaves from dark-green pUM79 transformants contained normal levels of LS RubisCO (not shown). Hindlll digests of pUM79 transformant DNA gave $7.0 \mathrm{kbp} \mathrm{rbcL}$ (Figure 4a, lanes 5 and 6) and $4.6 \mathrm{kbp} a c c \mathrm{D}$ bands (Figure 4c, lanes 5 and6), compatible with the integration pattern of pUM79 (Figure 1b). 
The absence of a $9.6 \mathrm{kbp}$ Hindlll $a c c \mathrm{D}$ band, diagnostic of $\Delta r b c \mathrm{~L}$ plants (Figure 4c, lanes 3 and 4) in pUM79 transformants (Figure 4c, lanes 5 and 6 ) indicates that the $\Delta r b c L$ plastid genomes have been replaced with a homoplasmic population of transgenic pUM79 plastid genomes. An aadA probe hybridized to the expected $4.1 \mathrm{kbp}$ Hindlll band in digests of DNA from pUM79 transformant clone 1 (Figure 4d, lane 5).

\section{Discussion}

We have described a precise and simple method for deleting the plastid $r b c \mathrm{~L}$ gene following a single transformation step. The precision of homology-based excision is demonstrated by the presence of only five foreign bases (GGCCG) in the $\Delta r b c L$ plastid genome described here. The deletion (co-ordinates 57 424-59 317; Wakasugi et al., 2001) removes the $1434 \mathrm{bp} r b c \mathrm{~L}$ coding region, $171 \mathrm{bp}$ of upstream and $289 \mathrm{bp}$ of downstream sequences. This makes the mutant suitable for plastid transformation with vectors containing changes in the $r b c \mathrm{~L}$ coding sequence for structure-function studies (Andrews and Whitney, 2003; Parry et al., 2003; Spreitzer et al., 2005) and in the regulatory region (Shiina et al., 1998) to modify rbcL expression levels. Rescue of the mutant phenotype by the WT rbcL allele following aadA-based plastid transformation rules out mutations at other sites.

A relatively long duplication of $649 \mathrm{bp}$ separated by $5.4 \mathrm{kbp}$ was used because excision was barely detected between two copies of a 418 bp psbA $3^{\prime}$ regulatory region spaced $1 \mathrm{kbp}$ apart (lamtham and Day, 2000). The influence of sequence composition on rates of plastid recombination is not known. High levels of sectoring in leaves of $T_{1}$ plants indicated efficient excision of the $r b c \mathrm{~L}$ gene. Excision products were also detected in the $\mathrm{T}_{0}$ generation by DNA blot analyses. This indicates that it should be possible to visualize mutant sectors in leaves of $T_{0}$ plants following vegetative propagation and additional cycles of regeneration on non-selective medium. Cytoplasmic sorting is an essential component of the method because it drives the segregation of different plastid types and leads to the isolation of homoplasmic mutants in the absence of selection. Use of site-specific recombinases is less reliant on cytoplasmic sorting because, in principle, they allow simultaneous excision of genes from multiple plastids (Kuroda and Maliga, 2003).

Deletion of native plastid genes and foreign genes in one recombination event simplifies the isolation of plastid mutants lacking foreign genes. The method has the added advantage of allowing any two regions of ptDNA to be spliced together by recombination and reduces the reliance on the proximity of convenient restriction sites to delete plastid genes. The approach also allows the deletion of multiple adjacent plastid genes. A duplication of the region downstream of the atpE gene would delete the $r b c \mathrm{~L}$, atpB and atpE genes in one step. Deletion of plastid genes that do not confer a pigment-deficient phenotype, such as the $n d h$ genes (Burrows et al., 1998; Kofer et al., 1998) would require PCR-based screening of seedlings or shoots from vegetatively propagated plants. Only regions of the plastid genome lacking essential genes can be deleted by this approach. In tobacco, essential genes include clpP1 (Kuroda and Maliga, 2003; Shikanai et al., 2001), ycf1, ycf2 (Drescher et al., 2000) and accD (Kode et al., 2005) as well as plastid-encoded components of the plastid translation machinery such as rps14 (Ahlert et al., 2003) that are needed to express these genes.

Restoration of photosynthesis following aadA-based plastid transformation with the WT rbcL allele helps to maintain recombinant plastid genomes when antibiotic selection is removed in soil-grown plants. When WT plants are transformed, residual heteroplasmy in soil-grown plants can be a problem if stochastic fluctuations or selective forces lead to a reduction in transgenic plastids relative to WT plastids. One cycle of regeneration usually suffices to isolate homoplasmic transplastomic plants following mutant rescue in agreement with the results of Klaus et al. (2003). We were unable to use restoration of photosynthesis as the sole criterion for selecting plastid transformants (results not shown). The reasons for this failure are unclear but others have also had little success with this approach (Klaus et al., 2004).

In Chlamydomonas (Goldschmidt-Clermont, 1991), moss (Sugiura and Sugita, 2004) and all angiosperm species in which stable plastid transformation has been reported (see below), transforming DNA integrates by homologous recombination. In addition to tobacco, stable transformation of angiosperm plastids has been reported in Arabidopsis thaliana (Sikdar et al., 1998), carrot (Kumar et al., 2004a), cauliflower (Nugent et al., 2006), cotton (Kumar et al., 2004b), Lesquerella fendleri (Skarjinskaia et al., 2003), lettuce (Lelivelt et al., 2005), petunia (Zubko et al., 2004), potato (Sidorov et al., 1999), soybean (Dufourmantel et al., 2004) and tomato (Ruf et al., 2001). Conservation of the homologous recombination pathway in plastids from divergent species makes homology-based excision a suitable method for manipulating ptDNA in a wide variety of plants.

\section{Experimental procedures}

\section{Vector construction}

Vectors were made by standard cloning techniques (Sambrook et al., 1989). The atpB $5^{\prime}$ regulatory region including the ATG initiation codon were amplified with primers atpB-Notl-F $5^{\prime}$ CCGCGGCCGCCAAATACATCATTATTGTATAC (underlined complement of 57423 to $57400 \mathrm{bp}$ ) in $155939 \mathrm{bp}$ tobacco plastome (accession number Z00044) and atpB-Ncol-R CCCCATGGACATA- 
ATAATAAAATAAATAAATATG (underlined positions 56775 to $56799 \mathrm{bp}$ ). The amplified product was cloned into the EcoRV site of pBluescript to make pBS- $5^{\prime} \mathrm{NtatpB}$ and sequenced to ensure the absence of PCR mutations. A uidA coding sequence terminated by a $3^{\prime} \mathrm{NtpsbA}$ regulatory element (lamtham and Day, 2000) and flanked by $\mathrm{Ncol}$ and $\mathrm{Notl}-\mathrm{Sacl}$ sites was excised as a Ncol-Sacl fragment and ligated to Ncol- plus Sacl-digested pBS-5'NtatpB. The $5^{\prime} \mathrm{NtatpB}-$ uidA- $3^{\prime}$ NtpsbA expression cassette was then excised with Notl and cloned in inverted orientation with respect to a $16 \mathrm{SrrnBn}$-aadABnpsbC cassette (Zubko et al., 2004) into the Notl site of pTB27-link (Zubko et al., 2004) to make pUM83. In the transformation vector pUM79, the NtatpB-uidA-NtpsbA expression cassette is replaced with a CratpA-uidA-NtpsbA cassette, where CratpA is the $5^{\prime}$ regulatory region present in a $680 \mathrm{bp} \mathrm{EcoRI-Ncol} \mathrm{fragment} \mathrm{from} \mathrm{pUC-}$ atpX (Goldschmidt-Clermont, 1991; accession number J01399 bases 259-911). Accession numbers are AJ276677 (16SrrnBn), AJ578474 (BnpsbC), X02340 (aadA, modified by Goldschmidt-Clermont, 1991), U12369 (uidA).

\section{Isolation of transplastomic plants}

Plastid transformants were isolated following particle bombardment as described previously (Kode et al., 2005). Following bombardment of WT leaves, resistant shoots were selected on RMOP medium (Svab and Maliga, 1993) containing spectinomycin dihydrochloride pentahydrate plus streptomycin sulphate (Melford Lab Ltd, Chelsworth, UK), each at $500 \mathrm{mg} \mathrm{I}^{-1}$. Following three cycles of regeneration on RMOP medium with both antibiotics, shoots were rooted on Murashige and Skoog (MS) medium containing $200 \mathrm{mg} \mathrm{l}^{-1}$ spectinomycin. When $\Delta r b c \mathrm{~L}$ leaves were used for transformation, resistant shoots were isolated on RMOP medium containing spectinomycin $\left(500 \mathrm{mg} \mathrm{l}^{-1}\right)$ and transferred for rooting on MS medium with spectinomycin $\left(200 \mathrm{mg} \mathrm{I}^{-1}\right)$ or MS medium lacking antibiotics after one cycle of regeneration. All solid RMOP medium was prepared with $0.7-0.8 \% \mathrm{w} / \mathrm{v}$ agar. Either $0.7 \%$ agar or $0.25 \%$ Phytagel (Sigma-Aldrich, Poole, UK) was used to solidify MS media for rooting. Leaf pieces were stained in X-Gluc to monitor GUS expression as described previously (Jefferson, 1987).

\section{DNA manipulations}

Total DNA was prepared using the Wizard genomic plant DNA purification kit (Promega, Madison, WI, USA). DNA blot analyses procedures, hybridization probes, PCR analyses using purified DNA or crude DNA preparations as template DNA with ReadyMix Taq containing $\mathrm{MgCl}_{2}$ (Sigma-Aldrich, Poole, UK) were performed as described previously (Kode et al., 2005). Oligonucleotides (SigmaAldrich, Haverhill, UK) used for primers were ( $F$, forward; $R$, reverse) pt F 5'-CAACACTATCTCGACCTTGA-3' (tobacco plastid map locations 56 612-56 631), pt R 5'-GCATGAAAATACAATAGATGAATAG$3^{\prime}$ (complement 59 797-59 821), pt F1 5'-GCAGTGGACGTTTTGGATAAG-3' (59 005-59 025), aadA-F 5'-ATTCTCCGCGCTGTAGAAGTCACC-3' and aadA-R 5'-TACATTTCGCTCATCGCCAGCC-3'. PCR products and restriction fragments fractionated on $0.8-2 \%$ agarose gels were purified using the Perfectprep Gel Cleanup kit (Eppendorf AG, Hamburg, Germany). Purified PCR products and plasmids were sequenced from appropriate primers by cycle sequencing using the Big Dye terminator sequencing ready reaction kit (Applied Biosystems, Warrington, UK). DNA sequences were analysed using the Vector NTI version 9 suite of DNA analysis programs (Invitrogen, Carlsbad, CA, USA).

\section{Microscopy}

Sections were prepared as described previously (Kode et al., 2005) for transmission electron microscopy using an FEI Tecnai 12 Biotwin transmission electron microscope (FEl company, Eindhoven, The Netherlands).

\section{Acknowledgements}

Supported by Overseas Research Students awards to V. Kode and S. lamtham, a University Research Studentship award to V. Kode and a Royal Thai Government Scholarship to S. lamtham. We thank the electron microscopy and DNA sequencing facilities for assistance.

\section{References}

Ahlert, D., Ruf, S. and Bock, R. (2003) Plastid protein synthesis is required for plant development in tobacco. Proc. Natl Acad. Sci. USA, 100, 15730-15735.

Andrews, T.J. and Whitney, S.M. (2003) Manipulating ribulose bisphosphate carboxylase/oxygenase in the chloroplasts of higher plants. Arch. Biochem. Biophys. 414, 159-169.

Burrows, P.A., Sazanov, L.A., Svab, Z., Maliga, P. and Nixon, P.J. (1998) Identification of a functional respiratory complex in chloroplasts through analysis of tobacco mutants containing disrupted plastid ndh genes. EMBO J. 17, 868-876.

Carrer, H. and Maliga, P. (1995) Targeted insertion of foreign genes into the tobacco plastid genome without physical linkage to the selectable marker gene. Biotechnology, 13, 791-794.

Carrer, H., Hockenberry, T.N., Svab, Z. and Maliga, P. (1993) Kanamycin resistance as a selectable marker for plastid transformation in tobacco. Mol. Gen. Genet. 241, 49-56.

Corneille, S., Lutz, K., Svab, Z. and Maliga, P. (2001) Efficient elimination of selectable marker genes from the plastid genome by the CRE-lox site-specific recombination system. Plant J. 27, 171178.

Corneille, S., Lutz, K.A., Azhagiri, A.K. and Maliga, P. (2003) Identification of functional lox sites in the plastid genome. Plant J. 35, 753-762.

Drescher, A., Ruf, S., Calsa, T., Carrer, H. and Bock, R. (2000) The two largest chloroplast genome-encoded open reading frames of higher plants are essential genes. Plant J. 22, 97-104.

Dufourmantel, N., Pelissier, B., Garcon, F., Peltier, G., Ferullo, J.M. and Tissot, G. (2004) Generation of fertile transplastomic soybean. Plant Mol. Biol. 55, 479-489.

Fischer, N., Stampacchia, O., Redding, K. and Rochaix, J.D. (1996) Selectable marker recycling in the chloroplast. Mol. Gen. Genet. 251, 373-380.

Goldschmidt-Clermont, M. (1991) Transgenic expression of aminoglycoside adenine transferase in the chloroplast: a selectable marker for site-directed transformation in Chlamydomonas. $\mathrm{Nu}$ cleic Acids Res. 19, 4083-4089.

Hajdukiewicz, P.T.J., Gilbertson, L. and Staub, J.M. (2001) Multiple pathways for Cre/lox-mediated recombination in plastids. Plant $J$. 27, 161-170.

Huang, F.C., Klaus, S.M.J., Herz, S., Zou, Z., Koop, H.U. and Golds, T.J. (2002) Efficient plastid transformation in tobacco using the aphA-6 gene and kanamycin selection. Mol. Genet. Genomics, 268, 19-27.

Huang, C.Y., Grunheit, N., Ahmadinejad, N., Timmis, J.N. and Martin, W. (2005) Mutational decay and age of chloroplast and mitochondrial genomes transferred recently to angiosperm nuclear chromosomes. Plant Physiol. 138, 1723-1733. 
lamtham, S. and Day, A. (2000) Removal of antibiotic resistance genes from transgenic tobacco plastids. Nat. Biotechnol. 18, 1172-1176.

Jefferson, R. (1987) Assaying chimeric genes in plants: the GUS gene fusion system. Plant Mol. Biol. Rep. 5, 387-405.

Kanevski, I. and Maliga, P. (1994) Relocation of the plastid $r b c l$ gene to the nucleus yields functional ribulose-1,5-bisphosphate carboxylase in tobacco chloroplasts. Proc. Natl Acad. Sci. USA, 91, 1969-1973.

Klaus, S.M.J., Huang, F.C., Eibl, C., Koop, H.U. and Golds, T.J. (2003) Rapid and proven production of transplastomic tobacco plants by restoration of pigmentation and photosynthesis. Plant J. 35, 811821.

Klaus, S.M.J., Huang, F.C., Golds, T.J. and Koop, H.U. (2004) Generation of marker-free plastid transformants using a transiently cointegrated selection gene. Nat. Biotechnol. 22, 225-229.

Kode, V., Mudd, E.A., lamtham, S. and Day, A. (2005) The tobacco plastid $a c c \mathrm{D}$ gene is essential and is required for leaf development. Plant J. 44, 237-244.

Kofer, W., Koop, H.U., Wanner, G. and Steinmuller, K. (1998) Mutagenesis of the genes encoding subunits $\mathrm{A}, \mathrm{C}, \mathrm{H}, \mathrm{I}, \mathrm{J}$ and $\mathrm{K}$ of the plastid NAD(P)H-plastoquinone-oxidoreductase in tobacco by polyethylene glycol-mediated plastome transformation. Mol. Gen. Genet. 258, 166-173.

Kumar, S., Dhingra, A. and Daniell, H. (2004a) Plastid-expressed betaine aldehyde dehydrogenase gene in carrot cultured cells, roots, and leaves confers enhanced salt tolerance. Plant Physiol. 136, 2843-2854.

Kumar, S., Dhingra, A. and Daniell, H. (2004b) Stable transformation of the cotton plastid genome and maternal inheritance of transgenes. Plant Mol. Biol. 56, 203-216.

Kuroda, H. and Maliga, P. (2003) The plastid clpP1 protease gene is essential for plant development. Nature, 425, 86-89.

Lelivelt, C.L.C., McCabe, M.S., Newell, C.A., de Snoo, C.B., van Dun, K.M.P., Birch-Machin, I., Gray, J.C., Mills, K.H.G. and Nugent, J.M. (2005) Stable plastid transformation in lettuce (Lactuca sativa L.) Plant Mol. Biol. 58, 763-774.

Lutz, K.A., Corneille, S., Azhagiri, A.K., Svab, Z. and Maliga, P. (2004) A novel approach to plastid transformation utilizes the phiC31 phage integrase. Plant J. 37, 906-913.

Lutz, K.A., Bosacchi, M.H. and Maliga, P. (2006) Plastid marker-gene excision by transiently expressed CRE recombinase. Plant J. 45, 447-456

Maliga, P. (2005) New vectors and marker excision systems mark progress in engineering the plastid genome of higher plants. Photochem. Photobiol. Sci. 4, 971-976.

Nugent, G.D., Coyne, S., Nguyen, T.T., Kavanagh, T.A. and Dix, P.J. (2006) Nuclear and plastid transformation of Brassica oleracea var. botrytis (cauliflower) using PEG-mediated uptake of DNA into protoplasts. Plant Sci. 170, 135-142.

Parry, M.A.J., Andralojc, P.J., Mitchell, R.A.C., Madgwick, P.J. and Keys, A.J. (2003) Manipulation of RubisCO: the amount, activity, function and regulation. J. Exp. Bot. 54, 1321-1333.

Ruf, S., Hermann, M., Berger, I.J., Carrer, H. and Bock, R. (2001) Stable genetic transformation of tomato plastids and expression of a foreign protein in fruit. Nat. Biotechnol. 19, 870-875.
Sambrook, J., Fritsch, E.F. and Maniatis, T. (1989) Molecular Cloning: A Laboratory Manual, 2nd edn. Cold Spring Harbor, NY: Cold Spring Harbor Laboratory Press.

Shiina, T., Allison, L. and Maliga, P. (1998) rbcL transcript levels in tobacco plastids are independent of light: reduced dark transcription rate is compensated by increased mRNA stability. Plant Cell, 10, 1713-1722.

Shikanai, T., Shimizu, K., Ueda, K., Nishimura, Y., Kuroiwa, T. and Hashimoto, T. (2001) The chloroplast clpP gene, encoding a proteolytic subunit of ATP-dependent protease, is indispensable for chloroplast development in tobacco. Plant Cell Physiol. 42, 264-273.

Sidorov, V.A., Kasten, D., Pang, S.Z., Hajdukiewicz, P.T.J., Staub, J.M. and Nehra, N.S. (1999) Stable chloroplast transformation in potato: use of green fluorescent protein as a plastid marker. Plant J. 19, 209-216.

Sikdar, S.R., Serino, G., Chaudhuri, S. and Maliga, P. (1998) Plastid transformation in Arabidopsis thaliana. Plant Cell Rep. 18, 20-24.

Skarjinskaia, M., Svab, Z. and Maliga, P. (2003) Plastid transformation in Lesquerella fendleri, an oilseed Brassicacea. Transgenic Res. 12, 115-122.

Spreitzer, R.J., Peddi, S.R. and Satagopan, S. (2005) Phylogenetic engineering at an interface between large and small subunits imparts land-plant kinetic properties to algal RubisCO. Proc. Natl Acad. Sci. USA, 102, 17225-17230.

Sugiura, C. and Sugita, M. (2004) Plastid transformation reveals that moss tRNA(Arg)-CCG is not essential for plastid function. Plant $J$. 40, 314-321.

Svab, Z. and Maliga, P. (1993) High frequency plastid transformation in tobacco by selection for a chimeric aadA gene. Proc. Natl Acad. Sci. USA, 90, 913-917.

Svab, Z., Hajdukiewicz, P. and Maliga, P. (1990) Stable transformation of plastids in higher-plants. Proc. Natl Acad. Sci. USA, 87, 8526-8530.

Swiatek, M., Regel, R.E., Meurer, J., Wanner, G., Pakrasi, H.B., Ohad, I. and Herrmann, R.G. (2003) Effects of selective inactivation of individual genes for low-molecular-mass subunits on the assembly of photosystem II, as revealed by chloroplast transformation: the psb EFLJ operon in Nicotiana tabacum. Mol. Genet. Genomics, 268, 699-710.

Wakasugi, T., Tsudzuki, T. and Sugiura, M. (2001) The genomics of land plant chloroplasts: gene content and alteration of genomic information by RNA editing. Photosyn. Res. 70, 107118.

Whitney, S.M., von Caemmerer, S., Hudson, G.S. and Andrews, T.J. (1999) Directed mutation of the Rubisco large subunit of tobacco influences photorespiration and growth. Plant Physiol. 121, 579588.

Ye, G.N., Colburn, S.M., Xu, C.W., Hajdukiewicz, P.T.J. and Staub, J.M. (2003) Persistence of unselected transgenic DNA during a plastid transformation and segregation approach to herbicide resistance. Plant Physiol. 133, 402-410.

Zubko, M.K., Zubko, E.I., van Zuilen, K., Meyer, P. and Day, A. (2004) Stable transformation of petunia plastids. Transgenic Res. 13, 523-530. 